\title{
An Optimistic View of World Food Prospects
}

\author{
Ron Duncan
}

A NALYSES of world food prospects usually concentrate on the alleged limitations of agricultural resources and rapid population growth. The likely effects of rapid income growth in the most populous parts of the world are generally neglected, as are the continuing sharp decline in population growth rates and price responses in terms of input or output substitution.

Concerns about future food production reflect doubts about the ability of agricultural research to maintain its outstanding performance of the post-World War II period, whether because further scientific breakthroughs may not be forthcoming or because governments may not be willing to fund agricultural research sufficiently. Concern also exists about soil erosion or degradation, declining water quality, diminishing germplasm resources, and further increases in cultivatable land or water supplies.

In this article, an assessment is made of the argument that a growing imbalance exists between world population numbers and the world's ability to feed them. It is argued that such problems as exist are mostly man-made and can be corrected. In particular, poor policies and the absence of effective property rights are responsible for many of the problems affecting the resource base.

\section{Improving Global Food Security}

The great increase in food security since World War II has gone largely unrecognised, apart from the major contribution of the so-called Green Revolution. Television images of malnourishment and death from starvation on the African continent are regrettably common; but it is seldom noted that such disasters are due more to civil war and misguided economic policies which have weakened the farming systems of those countries than to limitations of the agricultural resource base and technology. Cleaver (1993) and Cleaver and Schreiber (1992) identify production constraints such as inadequate land-tenure systems and neglect of infrastructure, which, they argue, are compounded by poor economic and agricultural policies and political instability. In global terms, however, the output of cereals the main food source for most people) has increased by around 2.7 per cent a year

Ron Duncan is Professor of Economics and Executive Director of the National Centre for Development Studies, Research School of Pacific and Asian Studies, The Australian National University. 
since 1950 , while the world's population has grown by about 1.9 per cent a year. To put it another way: cereals output per person has increased by almost 1 per cent a year for over 40 years, when the world's population has been growing faster than ever before. Cereal yields alone have increased by 2.25 per cent a year since 1950: faster than the rate of population growth. The Food and Agriculture Organisation of the United Nations estimates that total food production has grown by 35.4 per cent per head over the 1961-96 period in high-income countries, and by 50.8 per cent in developing countries. Within developing-country regions, Asia experienced the largest increase ( 70.3 per cent), followed by Latin America ( 31.9 per cent). In Africa, food production per head fell by around 1 per cent a year over this 30-year period (FAOSTAT Database).

Within the populous Asian region, food production performances have been extraordinary. China increased food production per head by 165.7 per cent in the 1961-96 period as the result of rapid increases in food production, with a population growth of 1.8 per cent. Indonesia increased food production per head by 69.6 per cent, even though its population grew at the reasonably rapid rate of 2.3 per cent. The increasing proportion of well-fed people in the world is largely due to the gains in Asia, where approximately 60 per cent of the world's population live. Africa accounts for only 12 per cent of the global population, though its share is increasing because it now has the fastest growth rate.

\section{Waiting for Malthus}

Beginning with Thomas Malthus in his Essay on the Principle of Population as it Affects the Future Improvement of Society in 1798, many commentators have been willing to foresee disaster in a looming imbalance between population and food growth. More recently, Ehrlich (1968), for example, forecast starvation on a massive scale within the decade after the publication of his book, and urged strict population controls. Although the expected disasters have not happened, in recent years concern has again been rising, led in particular by Lester Brown of the Worldwatch Institute in the United States, about the allegedly adverse impact of population growth and income growth on soil, water and air: an impact that is expected to severely damage the planet's food production capacity.

Taking an extremely pessimistic position on the spectrum of views on the world food outlook, Brown and Kane (1994) argue that a shrinking backlog of unused agricultural technology is coinciding with declining public interest in funding agricultural research; that the demands for water are pressing against hydrologic limits; that the response of crops to additional fertiliser applications is declining in many countries; and that cropland is being substantially reduced by industrialisation and ur-

\footnotetext{
Other well-known pessimists are Paddock and Paddock (1976) and Herman Daly (1980, 1996). The modern anti-natal movement, which appears to have racist and eugenic roots, uses arguments about the adverse effects of population growth on economic growth and environmental quality, even though there is no convincing evidence that faster population growth in itself reduces income growth, increases poverty or hastens environmental degradation.
} 
banisation. Moreover, they believe that seafood production has reached its biological limits and that the carrying capacity of rangelands has been exceeded - which places an additional burden on cropland to provide increased food supplies.

In another book which has created considerable anxiety in China, Brown (1995) advances a scenario wherein China's grain production declines from the $341 \mathrm{~m}$ tons produced in 1990 to $272 \mathrm{~m}$ tons by 2030 , basically because of competition for agricultural land from industrial and urban uses. ${ }^{2}$ On the assumption that consumption per head does not increase, population growth is projected to raise total consumption from the $346 \mathrm{~m}$ tons of 1990 to $479 \mathrm{~m}$ tons by 2030; if China's consumption per head increases to 400 kilograms - about the same level as Taiwan's today and one-half that of the United States - total consumption will reach $641 \mathrm{~m}$ tons by 2030 . The former consumption scenario leads to grain imports of $207 \mathrm{~m}$ tons by 2030 , while the latter leads to grain imports of $370 \mathrm{~m}$ tons. The first scenario envisages China importing the equivalent of today's global grain trade, while the second would nearly treble the global grain trade: an outcome which Brown sees as inconceivable.

\section{Future Food Demand}

In evaluating these and other less pessimistic forecasts of the world food outlook, attention should be paid not only to the perceived constraints on the supply side but also to whether reasonable judgments are being made about the future demand for food.

Alex McCalla, Director of the World Bank's Agriculture and Environment Department, has said that:

Everyone agrees that the world's population will exceed 8 billion people by 2025 ... everyone agrees that world food supplies will have to more than double by 2025, because of increases in income and urbanisation in addition to population growth. Given this widespread agreement on the needs or demand side of the equation and its magnitude ... why is there so little agreement on the ease or difficulty of generating the supply to meet that demand? (McCalla, 1994:1)

But is this increase in demand so certain, even if we disregard the usual neglect of what might happen as a result of changes in food prices in the various scenarios? The demand for food is dependent on population size and on the effect of income changes on food demand; but population size becomes the more important determinant as incomes increase. At very low income levels, 80-85 per cent of household income may be spent on food; so, as incomes increase from these low levels, food demand tends to grow very quickly. As incomes increase further, however, the marginal propensity to consume food falls. The consumption growth of the basic staple declines fastest. For example, the income elasticity for rice in China is

${ }^{2}$ China's grain production achieved a record $500 \mathrm{~m}$ tons in 1996. 
now believed to be negative (Ito et al., 1989; Peterson et al., 1991). At the income levels of the high-income countries, consumption growth per head of food changes very little. The world's cereal consumption per head has not increased appreciably since 1978. In developing countries, the average has not increased since 1984 . Given the rapid income growth achieved by a large proportion of the people in developing countries, the slowdown in consumption growth rates indicates that the most rapid phase of cereals consumption has already happened for most of the world's population. In developing countries which have experienced sustained income growth, dietary patterns have shown significant changes, with shifts away from staple sources of calonie supplies, such as rice or maize, towards wheat, and from calorie sources to protein sources such as meats, fruits and vegetables (see Mitchell et al., 1997). These dietary changes will continue as incomes rise, but the decline in the rate of growth of total food consumption per head can be expected to continue. In China, for example, real GDP grew substantially faster during the 1980s than during the 1970s, yet consumption of cereals grew by an average of 2.3 per cent a year during the $1980 \mathrm{~s}$ compared with 5.2 per cent a year during the $1970 \mathrm{~s}$.

As food consumption growth slows with increasing incomes, population plays a more important role in food demand. But the population growth rate is also slowing rapidly: from 2.06 per cent in $1965-70$ to 1.74 per cent in 1985-90. The World Bank (1992) projected that it could fall to between 0.57 and 1.41 per cent by 2020-25: a wide range that reflects the uncertainty surrounding population projections, mainly about the speed of the fertility slowdown in the demographic transition (Bongaarts, 1995). ${ }^{4}$ The reduction in fertility has been comparatively rapid in the fast-growing East Asian countries. Presumably, if Sub-Saharan Africa could generate sustained economic growth, population growth there would slow faster than demographers are presently forecasting. Moreover, its food consumption would increase faster than it has in recent decades, and then slow. Under the World Bank's low population growth rate, the world population would reach 7.6 billion in 2025 . The increase in the demand for food by 2025 , as determined by population and income growth, is therefore not as certain as McCalla assumes.

\section{How Limiting are the Supply Constraints?}

To meet future food demand, it appears that supply will not need to increase as fast as it has over the past 40 years. But, as we have seen, some argue that even a future rate of increase of around 1.7 per cent a year, as expected by the major forecasting agencies, will be frustrated by resource constraints. How realistic are the fears that Brown and Kane articulate?

Diminishing water supplies. It is widely agreed that achieving increases in water supplies does indeed pose problems, in terms of both the higher cost of additional

\footnotetext{
${ }^{3}$ In 1960-90, the real per head GDP of developing countries increased on average by 162 per cent.

"The total fertility rate is the number of births a woman would have by the end of her reproductive years if she experienced age-specific fertility rates of a given year.
} 
supplies and the declining quality of existing supplies (Rosegrant, 1997; Rosegrant \& Ringler, 1997). Groundwater supplies are being depleted in many regions as pumping exceeds replenishment, and rapidly growing household and industrialisation uses compete with agricultural uses.

But water losses and wastage in agriculture are high because, as Rosegrant (1997) points out, water is often available free or at highly subsidised prices." However, raising the price of water to cover its true cost (private and social) is usually politically difficult. As well, property rights are often not well or easily defined, as in transborder (between provinces or countries) situations; and until such difficulties are resolved water use will usually be inefficient. Developing the appropriate institutional mechanisms presents enormous challenges, particularly with regard to water resources shared among countries. But these challenges are being tackled, as exemplified in Australia by the formation of the Murray-Darling Basin Commission and the progress being made through the Commission in devising ways to share the basin waters more efficiently and to reduce the basin's severe salination problem. An international agreement has recently been drawn up on sharing the waters of the Mekong River, and discussions are taking place over sharing the waters of the Jordan and the Nile.

Land availability and land degradation. Buringh and Dudal (1987) estimate that less than one-half of the world's land area suitable for crop production is currently being used for this purpose. Much of the presently uncultivated area, however, is located in remote areas in Africa and South America. World cropland has hardly increased since 1960, while land under pastures and meadows has increased by around 30 per cent since 1960 . If yield increases can deliver the slower food production growth likely to be needed in the future, the additional cropland requirements will be minimal. These projected increases in crops include the demands for feeding livestock, which implies slower increases in pasture areas.

Crosson and Anderson (1992) argue that the various reports on the loss of arable land through erosion or chemical degradation were exaggerated; indeed, the losses claimed run counter to the increased yields realised from these soils over sustained periods. Rosegrant and Ringler (1997) agree. From his analysis of long-term data on soils in China and Indonesia, Lindert (1996) finds that, of the important ingredients of soils, organic matter and nitrogen do appear to have declined on cultivated lands in both countries, while total phosphorus and potassium have generally increased. Alkalinity and acidity have not worsened, nor has the topsoil layer become thinner. Though China's soil organic matter and nitrogen have declined, its crop yields do not appear to have been adversely affected: presumably, Lindert argues, because nitrogen fertilisers have been applied.

\footnotetext{
${ }^{5}$ Rosegrant and Ringler (1997) state that water-use efficiency in irrigation in much of the developing world is only in the $20-40$ per cent range.

${ }^{6}$ Worldwide there are around 200 shared river basins, most of them shared between two countries.
} 
Lindert identifies three aspects of economic development which may result in improved soil quality. First, if we take all soil-farming feedbacks into account, the shift in food demand away from staples toward legumes and animal products is likely to replenish soil nutrients. Second, development brings cheaper capital and clearer property rights, which improve conservation. Third, urbanisation and industrialisation raise the productivity of soils at the urban fringe.

In arguing that China's cereals production will fall well below its demand by 2030, Brown (1995) draws two parallels. First, in countries that, like China, began to industrialise when they were already densely populated (the examples he uses are Japan, Republic of Korea, and Tawan), farmland was largely converted to industrial and urban uses. Second, most of the world's major fishing stocks have been severely depleted because of the growth in population and incomes (particularly in Japan, where consumption of seafood products is comparatively high); in a similar fashion there will be a reduction in agricultural production in China because of over-use of agricultural land. But the logic of both arguments is faulty. If agricultural land is converted to other uses in the absence of government intervention, the country's welfare is increased, and the rise in incomes earned in these other uses can be used to purchase (import) the needed agricultural products. Given its high incomes and low ratios of land to capital and land to labour, it was clearly in Japan's interests to specialise in non-agricultural products. And although its grain production has fallen, Taiwan is a large exporter of other, more highly valued, agricultural products which it is better placed to produce than grains. As in Taiwan, China's comparative advantage in agricultural production is shifting away from landintensive crops such as grains towards more labour-intensive and higher-value crops such as fruit and vegetables (see Feng $\mathrm{Lu}, 1996$ ).

The depletion of fish and other marine-based stocks stems from the absence of effective property rights to marine resources and the consequent common access problem, resulting in over-exploitation (for discussion, see Iheduru, 1995; Williams, 1996). But it is clear that, even with effective marine property rights and management controls to ensure optimal harvest rates, the world's demands for seafoods cannot be met from unfarmed resources that allow no increases in productivity. Responding to the increasing prices of seafood products, the farming of fish and crustaceans has boomed, backed by scientific breakthroughs in breeding and farming methods.

The correct conclusion to draw with respect to Chinese agriculture, and agriculture more generally, is that farmers must be given secure property rights to land so that farming can be efficient and sustainable. As well, if agricultural land becomes scarcer and its price rises, other means of farming involving land-substitution practices will be devised. But, unlike with seafoods, whose price increases triggered the search for other forms of production, there has been no sustained increase in prices of agricultural products signalling the need for a major increase in research effort. In fact, agricultural prices have continued to trend downwards in real terms, at least as measured in terms of wages. 
The problem of farmers' insecure property rights to land needs to be addressed in many developing and transition countries where productivity growth is urgently required for enhanced food security. Discussions with World Bank staff stationed in Moscow suggest that the Russian Federation's poor recent agricultural performance is basically the result of the absence of long-term security of land tenure for individual farmers. By contrast, the extension of reasonably long-term access to land for individual farmers in China and Vietnam was a key reason, together with market-based prices, for the increase in their productivity (see McMillan et al., 1989). In China, the original 15-year leases were extended for another 30 years in 1995. To allow scope for improved productivity through increased farm size, the leases should also be made transferable.

It is also clear that, in many developing countries, more secure property rights to land - whether freehold or long-term leasehold tenure - and cuts to the punishing taxes frequently imposed on agriculture are needed to prevent further soil degradation and even to improve soil quality. In most cases, the most appropriate management of land and water resources will be achieved by institutional developments (the creation of property rights and of markets for trading in those rights) which internalise the external costs associated with their use. ${ }^{7}$ This may well mean that marginal land will no longer be farmed (or not farmed as intensively), or that water use in agriculture will be reduced in response to higher prices. But, overall, resource allocation and social welfare will be improved. The impact of any consequent reductions in resource use should be more than offset by the improved productivity from the institutional developments. More secure access to land and water should lead to greater investment in land, including investment that promotes soil and water conservation, which in turn should lead to higher and more stable output.

Prospects for continued yield increases. The pessimists argue that crop yields have slowed over the past decade or so, for reasons such as the declining response to increases in fertiliser applications, and slower development of improved varieties. A different view, argued above, is that yields do not need to grow as fast as in the past, because demand growth is slowing. But how likely is it that slower rates of cereals yield growth, of around 1.5 per cent or even 2 per cent a year if required, can be achieved over the next $30-40$ years?

Yield increases can be achieved either by extending the use of known technology or by the development of new technology such as improved crop varieties, improved fertilisers, or improved farming practices. Large gaps between on-farm and experimental yields exist in many developing and transition economies due to the lack of application of existing technologies. Closure of these gaps should be greatly

\footnotetext{
7 Jacobsen et al. (1996) discuss the creation of effective property rights within a communal setting which led to much more effective use of soil and water resources and reduction of external costs from soil and water run-off. Hanstad and Li Peng (1995) report on an experiment in the auctioning of transferable use rights to some of the $33 \mathrm{~m}$ hectares of 'wasteland' in China and Luliang Province (this is uncultivated but reclaimable land which was not distributed to householders during decollectivisation). It is claimed that the secure access to use rights will reduce soil erosion and increase forest cover.
} 
enhanced by improved institutions and policies, particularly more secure property rights to land, lower taxation of agriculture, and liberalisation of output and input (particularly fertiliser) markets. As well, there is ample room for improving the scope for yield-increasing new technologies as theoretical maximum yields - determined by photosynthetic potential, land quality, length of growing season and water availability - are many times higher than actual yields on average (Plucknett, 1995). The challenge is for research to provide the knowledge needed to reduce this gap.

Despite concern about the loss of biodiversity from developmental activities such as forest clearing, very substantial stocks of germplasm of the major food crops are held by research bodies in various countries (Wright, 1996). Enough germplasm is available in storage banks, quite apart from what might be available in situ, to support future conventional plant breeding research and biotechnology applications. Research applying biotechnology techniques holds the potential to improve crop yields through introducing higher plant resistance to pests and diseases, higher tolerance to adverse weather (such as drought) or soil conditions (such as salinity) and improved responses to fertilisers. Plant breeding can thus substitute for declining availability of good quality arable land, just as research into soil nutrition can increase the availability of arable land (as it has in Australia).

Research in the improvement in fertiliser responsiveness should have a high pay-off as levels of application of fertiliser in relatively favourable farming areas in Asia are now quite high and response rates appear to be slowing. Crop productivity can be raised without increased fertiliser use by improving nutrient uptake efficiency and nutrient balance (Rosegrant \& Pingali, 1994). Improved efficiency of fertiliser use is also needed to reduce the impact of fertiliser run-off on water supplies. This is a problem in Western Europe and parts of other high-income countries; but, except for intensively cultivated areas of East Asia, developing countries use too little fertiliser, which reduces soil fertility and increases erosion (Rosegrant \& Ringler, 1997). This under-utilisation of fertiliser is often attributable to fertiliser import restrictions, which provide privileged interests with monopoly rents.

\section{Conclusions}

Concerns about an impending or even distant global imbalance between population growth and food supplies are exaggerated. The major problems in the food supply system are either man-made or can be corrected through institutional developments. Pessimistic commentators generally ignore the effect on food consumption growth rates of the substantial increases in incomes achieved by a large proportion of the people in the developing world. This, together with their rapidly slowing population growth rates, means that future growth in cereals consumption will not be nearly as fast as it has been during the past 40 or so years - the period of most rapid growth of the world's population. As a result, food supplies do not need to grow as fast as they have in recent decades. Moreover, the concerns about future production growth are generally not warranted: or, if warranted, the causes and proposed solutions are misplaced. 
Increasing water supplies will be difficult and costly; but much can be done to make the use of existing supplies more efficient. Water is too often unpriced to farmers; despite the political difficulties, this has to change. Sharing of water supplies across countries also challenges policy-makers to devise institutions which achieve the most efficient utilisation of water supplies.

Establishing long-term, secure access to land for farmers is the most urgent need in many developing and transition countries and will make the greatest contribution to their food security. With secure access, farmers are more willing to invest in the land and adopt improved technologies, leading to higher productivity and reduced soil loss and degradation.

Besides market failure reflecting the lack of appropriate property rights in land and water, extensive policy failures in many developing countries adversely affect agriculture through excessive taxation of agricultural output, either directly or indirectly (such as through over-valued exchange rates or import restrictions on fertilisers). Again, reforming these policies will be resisted by special interests, such as urban populations that enjoy subsidised food prices.

It is, of course, uncertain whether research can continue to generate the necessary knowledge to keep yields increasing by extending the production capacity of land through substitution for natural resources. In a sense, land ceased to be a limiting constraint in the post-World War II period as a result of scientific discoveries. In view of the base of scientific knowledge which has been established in the 20th century, there are no grounds for pessimism about the potential for further scientific discovery. While the scope for private agricultural research has increased with the development of property rights in new technology, particularly biotechnology, there remains an important role for government funding of national and international research to increase agricultural productivity. But decisions about such funding should be based on objective analysis of the costs and benefits.

\section{References}

Bongaarts, J. (1995), 'Global and Regional Population Projections to 2025', pp. 7-22 in N. Islam (ed.), Population and Food in the Early Twenty-First Century: Meeting Future Food Demand of an Increasing Population, IFPRI, Washington DC.

Brown, L. (1995), Who will Feed China? Wake-up Call for a Small Planet, Norton, New York.

_ \& H. Kane (1994), Full House: Reassessing the Earth's Population Carnying Capacity, The Worldwatch Environmental Alert Series, Norton, New York.

Buringh, P. \& D. Dudal (1987), 'Agricultural Land Use in Time and Space', pp. 9-43 in M. Wolman \& F. Fournier (eds.), Land Transformation in Agriculture, Wiley, New York.

Cleaver, K. (1993), A Strategy to Develop Agriculture in Sub-Saharan Africa and a Focus for the World Bank, World Bank, Washington DC (World Bank Technical Paper 203).

\& G. Schreiber (1992), The Population, Agriculture, and Environment Nexus in Sub-Saharan Africa, World Bank, Washington DC (Agriculture and Rural Development Series 1).

Crosson, P. \& J. Anderson (1992), Resources and Global Food Prospects: Supply and Demand for Cereals to 2030, World Bank, Washington DC (World Bank Technical paper 184).

Daly, H. (1980), Economics, Ecology, Ethics, Freeman, San Francisco. 
(1996), 'Expanding an Important Consensus', Envinonment and Development Economics 1 (Part 1): 113-15.

Ehrlich, P. (1968), The Population Bomb, Ballantine Books, New York.

Food and Agriculture Organisation, FAOSTAT Database, Rome, at http://apps.fao.org.

Feng Lu (1996), 'China's Grain Trade Policy and Food Trade Pattern', RSPAS, Australian National University, Canberra (mimeo).

Hanstad, T. \& Li Peng (1995), 'Land Reform in China: Auctioning Rights to Wasteland', Rural Development Institute, Seattle (RDI Reports on Foreign Aid and Development No. 88).

Iheduru, O. (1995), 'The Political Economy of Euro-African Fishing Agreements', The Joumal of Developing Areas 30: 63-90.

Ito, S., W. Peterson \& W. Grant (1989), 'Rice in Asia: Is it Becoming an Inferior Good?' American Journal of Agricultural Economics 71: 32-42.

Jacobsen, V., J. Ashby \& G. Scobie (1996), 'Rules and Resources: Institutional Change for Natural Resource Management', Proceedings of Conference on Global Agricultural Science Policy for the Twenty-First Century, Melbourne (26-28 August).

Lindert, P. (1996), 'Soil Degradation and Agricultural Change in Two Developing Countries', Proceedings of Conference on Global Agricultural Science Policy for the Twenty-First Century, Melbourne (26-28 August).

McCalla, A. (1994), 'Agriculture and Food Needs to 2025: Why We Should be Concerned', Sir John Crawford Memorial Lecture, International Centers Week, Consultative Group on International Agricultural Research, World Bank, Washington DC (27 October).

McMillan, J., J. Whalley \& Lijing Zhu (1989), 'The Impact of China's Economic Reforms on Agricultural Productivity Growth', Journal of Political Economy 97: 781-807.

Mitchell, D., M. Ingco \& R. Duncan (1997), The World Food Outlook, Cambridge University Press, London.

Paddock, W. \& P. Paddock (1976), Famine-1975!, Little, Brown and Company, Boston.

Peterson, E., F. Wesley, J. Lau \& S. Ito (1991), 'Econometric Analysis of Rice Consumption in the People's Republic of China', Agricultural Economics 6: 67-8.

Plucknett, D. (1995), 'Prospects of Meeting Future Food Needs through New Technology', PP. 20720 in N. Islam (ed.), Population and Food in the Early Twenty-first Century: Meeting Future Food Demand of an Increasing Population, IFPRI, Washington DC.

Rosegrant, M. (1997), 'Water Resources in the Twenty-First Century: Challenges and Implications for Action', IFPRI, Washington DC (Food, Agriculture, and the Environment Discussion Paper 20).

Rosegrant, M. \& C. Ringler (1997), 'Environmental and Resource Policies: Implications for Global Food Markets', paper presented to the 41st Annual Conference of the Australian Agricultural and Resource Economics Society, Gold Coast (20-25 January).

Rosegrant, M. \& P. Pingali (1994), 'Policy and Technology for Rice Productivity Growth in Asia', Journal of International Development 6: 665-88.

Williams, M. (1996), The Transition in the Contribution of Living Aquatic Resources to Food Security, IFPRI, Washington DC (Food, Agriculture, and the Environment Discussion Paper 13).

World Bank (1992), World Population Projections, 1991-92, Washington DC.

Wright, B. (1996), 'Crop Genetic Resource Policy: Towards a Research Agenda' IFPRI, Washington DC (Discussion Paper No. 19).

The author is grateful to two anonymous referees for their helpful comments. 